\title{
PENGARUH KONSENTRASI BORON TERHADAP SIFAT LISTRIK LAPISAN TIPIS
} (a-Si:H:B)

\author{
Bambang Siswanto, Wirjoadi, Sudjatmoko \\ Puslitbang Teknologi Maju Batan Yogyakarta \\ Jl. Babarsari Kotak Pos 6101 ykbb, Yogyakarta 55281
}

\begin{abstract}
ABSTRAK
PENGARUH KONSENTRASI BORON TERHADAP SIFAT LISTRIK LAPISAN TIPIS (a-Si:H:B). Telah dilakukan deposisi bahan Si:B pada permukaan substrat kaca dengan teknik plasma sputtering DC. Deposisi dilakukan untuk beberapa parameter proses yang meliputi: waktu deposisi, tekanan gas dan suhu substrat dengan tujuan dapat diperoleh lapisan tipis (a-Si:H:B) yang mempunyai konduktivitas yang memadai sebagai bahan sel surya. Target adalah bahan silikon yang telah dicampur boron dengan konsentrasi $(0,1 ; 0,3 ; 0,5 ; 0,7) \%$ berat. Variasi waktu deposisi adalah (0,5 - 2) jam, tekanan gas $\left(1,1 \times 10^{-1}-1,4 \times 10^{-1}\right)$ Torr dan suhu substrat (150-300) ${ }^{\circ} \mathrm{C}$, sedangkan gas reaktif hidrogen selama proses deposisi dibuat tetap sebesar $4 \mathrm{sccm}$. Pengukuran sifat listrik dilakukan dengan probe empat titik, konduktivitas dihitung dengan pendekatan rumus matematik. Hasil penelitian menunjukkan bahwa resistansi terkecil sebesar $R=2,73 \times 10^{8} \Omega$, ini diperoleh pada kondisi percobaan, waktu deposisi 1,5 jam, tekanan gas $1,4 \times 10^{-1}$ Torr dan suhu substrat $200^{\circ} \mathrm{C}$. Dengan demikian dapat disimpulkan bahwa parameter proses di atas merupakan parameter deposisi yang optimum untuk pembuatan lapisan tipis (a-Si:H:B).
\end{abstract}

\section{ABSTRACT}

THE INFLUENCE OF BORON CONCENTRATION ON ELECTRICAL PROPERTIES OF (a-Si:H:B) THIN FILM. The Si:B materials have been deposited on glass substrate using plasma DC sputtering technique. The deposition process were performed with the following process parameters: the deposition time, gas pressure and substrate temperature with the aim to obtain a reasonable conductance as the solar cell material of (a-Si:H:B) thin film. The target was silicon material which was mixed by boron with concentration $(0.1 ; 0.3 ; 0.5 ; 0.7) \%$ weight. Variations of deposition time were $\left(0.5\right.$ - 2) hour, gas pressure $\left(1.1 \times 10^{-1}-1.4 \times 10^{-1}\right)$ Torr and substrate temperature $(150-300)^{\circ} \mathrm{C}$, while the hydrogen gas was kept constants at $4 \mathrm{sccm}$ during deposition. The resistance measurement has been done by four-point probe and the conductance was calculated using mathematic formulation. The results indicates that the minimum resistance of (a-Si:H:0.3B) thin film was $R=2.73 \times 10^{8} \Omega$, this was achieved at deposition time of 1.5 hours, gas pressure $1.4 \times 10^{-1}$ Torr and substrate temperature $200^{\circ} \mathrm{C}$. It could be concluded that the above process parameter is an optimum parameter for depositing the (a-Si:H:B) thin film

\section{PENDAHULUAN}

ada dekade ini teknik sputtering telah banyak digunakan dalam pembuatan lapisan tipis semikonduktor, karena dengan teknik ini dimungkinkan menghasilkan struktur yang serupa dengan bahan target yang dideposisikan. Khususnya dalam pembuatan lapisan tipis untuk bahan sel surya seperti (a-Si:H), biasanya jaringan silikon amorf yang terbentuk banyak lengan-lengan kosong (dangling bonds) sehingga untuk mengisi lengan-lengan kosong tersebut, maka pada waktu deposisi ditambahkan gas reaktif hidrogen. Sebagai akibatnya tingkat energi fermi akan tergeser ke arah pita valensi atau pita konduksi sehingga konduktivitas lapisan (a-Si:H) akan dapat dikontrol ${ }^{1,2]}$.

Secara umum susunan sel surya terdiri dari elektrode depan (sebagai pengumpul arus), sambungan semikonduktor pin (silicon amorf) dan elektrode belakang. Penelitian tentang sel surya telah banyak dilakukan terutama yang berhubungan dengan peningkatan efisiensi sel surya, diantaranya dengan mengoptimalkan kualitas lapisan tipis pada bagian semikonduktor pin sel surya, sedangkan konsentrasi dopan boron dan posfor sangat mempengaruhi konduktivitas lapisan tipis tipe- $P$ dan $N$ yang terbentuk. ${ }^{[3,4]} \quad$ Jika kualitas pembuatan lapisan tipis semikonduktor pin ini cukup baik maka efisiensi sel surya pun kemungkinan besar dapat meningkat.

Sehubungan dengan hal tersebut di atas maka diperperlukan optimasi pembuatan lapisan tipis semikonduktor pin, sehingga dapat dihasilkan suatu lapisan semikonduktor yang mempunyai resistansi yang memadai jika digunakan sebagai bahan sel surya. Resistansi dari semikonduktor tipe- $P$ lapisan tipis (a-Si:H) 
sekitar orde M $\Omega$ yang digunakan untuk sel surya telah dilaporkan oleh SWATI RAY, dkk., dengan metode $\mathrm{CVD}^{5^{5}}$. Juga doping boron mengakibatkan menurunnya resistansi dari lapisan tipis silikon amorf sampai orde $10^{\circ}$ ${ }^{4}$ dengan metode CVD, oleh ABHIJIT DE, $\mathrm{dkk}^{\left[{ }^{[0}\right.}$. Referensi tersebut menunjukkan suatu resistansi dari lapisan tipis silikon amorf orde $10^{7}-10^{9} \Omega$, ini ada indikasi bahwa resistansi lapisan tipis (a-Si:H) dalam orde tersebut di atas adalah cukup memadai jika digunakan sebagai bahan sel surya.

Apabila tabung reaktor plasma diisi gas argon dengan tekanan $(0,1-0,01)$ Torr, dan diberi tegangan DC beberapa kilovolt maka akan terjadi plasma lucutan pijar. Ion-ion argon yang terbentuk dalam plasma lucutan pijar dipercepat menuju ke katoda dan menumbuk permukaan target sehingga menimbulkan peristiwa sputtering. Jumlah bahan target yang tersputter dan kemudian terdeposit pada satuan luas permukaan substrat adalah,

$$
W \cong \frac{k_{t} W_{o}}{p d}
$$

dan laju deposisi $R\left(\AA /\right.$ min.cm² ${ }^{2}$ dapat dituliskan dalam persamaan :

$$
R=\frac{W}{t}
$$

dengan $k_{t}$ adalah suatu konstanta yang tergantung pada bentuk/geometri elektroda, $W_{o}$ adalah jumlah partikel yang tersputter per satuan luas target, $p$ adalah tekanan gas lucutan (Torr), $d$ adalah jarak elektroda (cm), $W$ adalah rapat lapisan yang tersputter $\left(\AA / \mathrm{cm}^{2}\right)$, dan $t$ adalah waktu sputtering. Jumlah partikel yang tersputter per satuan luas target dituliskan dalam bentuk persamaan :

$$
W_{0}=\frac{J_{+}}{e} S \cdot t \frac{A}{N_{A}}
$$

dengan $j_{+}$adalah rapat arus ion pada target (katoda), e adalah muatan elektron, $S$ adalah sputter yield, $A$ adalah berat atom dari bahan target yang tersputter, dan $N_{A}$ adalah bilangan Avogadro.

Berdasarkan rumusan di atas terlihat bahwa kualitas dan sifat-sifat lapisan tipis yang terdeposit pada permukaan substrat bergantung pada beberapa parameter sputtering diantaranya adalah : tekanan gas, waktu deposisi, suhu substrat, jarak elektrode, daya dan faktor geometri sistem elektrodenya ${ }^{\left[{ }^{7,8}\right]}$. Interaksi ion-ion energi tinggi dengan atom-atom sasaran menyebabkan tersputternya atom-atom target dan juga bergesernya atom-atom sasaran dari posisi awalnya sehingga terbentuk kekosongan (vacancies). Atom-atom target yang tersputter bertumbukan dengan molekul-molekul gas dan akhirnya tersebar pada permukaan karena tekanan gas sangat tinggi dan jalan bebas rata-rata dari partikel-partikel yang tersputter kurang dari jarak elektroda. Dengan berjalannya waktu deposisi maka ion-ion target yang terhambur akan menempati ruang kosong di sekitarnya secara sisipan (interstition) dan masuk ke dalam permukaan substrat secara difusi.

\section{TATA KERJA DAN PERCOBAAN}

Dalam penelitian ini dilakukan beberapa tahapan yang meliputi, preparasi cuplikan dan target, proses deposisi, dan karakterisasi hasil deposisi.

\section{Persiapan Target Dan Preparasi Cuplikan}

Bahan utama yang disiapkan dalam percobaan ini adalah bahan target dengan diameter $60 \mathrm{~mm}$, tebal 3 $\mathrm{mm}$ dari silikon yang telah dicampur boron kemudian diaduk sampai merata sebelum dibuat target dengan konsentrasi berat $(B / S i)=(0,1 ; 0,3 ; 0,5 ; 0,7) \%$. Kemudian substrat dari kaca preparat dengan ukuran $(10 \times 20)$ $\mathrm{mm}^{2}$, dicuci berturut-turut; pertama dengan air deterjen untuk menghilangkan kontaminasi senyawa organik maupun nonorganik pada permukaan substrat yang mungkin timbul pada pengerjaan sebelumnya, dilanjutkan dengan air bersih dan alkohol dalam ultrasonic cleanner, lalu dikeringkan dalam oven dan selanjutnya dibungkus dengan kertas tisu dan dimasukkan ke dalam kantong plastik. 


\section{Proses Deposisi Lapisan Tipis (a-Si:H:B)}

Peralatan sistem deposisi yang digunakan adalah plasma sputtering DC dengan komponen utama : tabung reaktor plasma, sistem elektrode (terdiri dari sepasang elektrode yang dipasang sejajar, satu sebagai tempat substrat dan yang satu sebagai tempat target), sistem catu daya tegangan tinggi $D C$, sistem vakum turbo molekular, rotari dan meter vakum, sistem pendingin target dan pemanas substrat dan sistem aliran gas ke tabung plasma. Substrat dipasang pada anode dan target dipasang pada katode di dalam tabung reaktor seperti terlihat pada Gambar 1, lalu dihampakan dengan sistem vakum rotari dan turbo, selanjutnya sistem pemanas dan sistem pengontrol aliran gas diatur sesuai parameter yang dikehendaki, kemudian catu daya tegangan tinggi DC dihidupkan sampai gas argon dan gas reaktif hidrogen dalam tabung reaktor terionisasi. Eksperimen dilakukan menggunakan target $\mathrm{Si}$ yang telah dicampur $(0,1 ; 0,3 ; 0,5 ; 0,7) \%$ boron dengan memvariasi parameter proses sputtering, antara lain : waktu deposisi $(0,5 ; 1 ; 1,5 ; 2)$ jam, tekanan gas $\left(1,1 \square 10^{-1} ; 1,2 \square 10^{-1}\right.$; $\left.1,3 \square 10^{-1} ; 1,4 \square 10^{-1}\right)$ Torr dan suhu substrat $(150 ; 200 ; 250 ; 300){ }^{\circ} \mathrm{C}$.

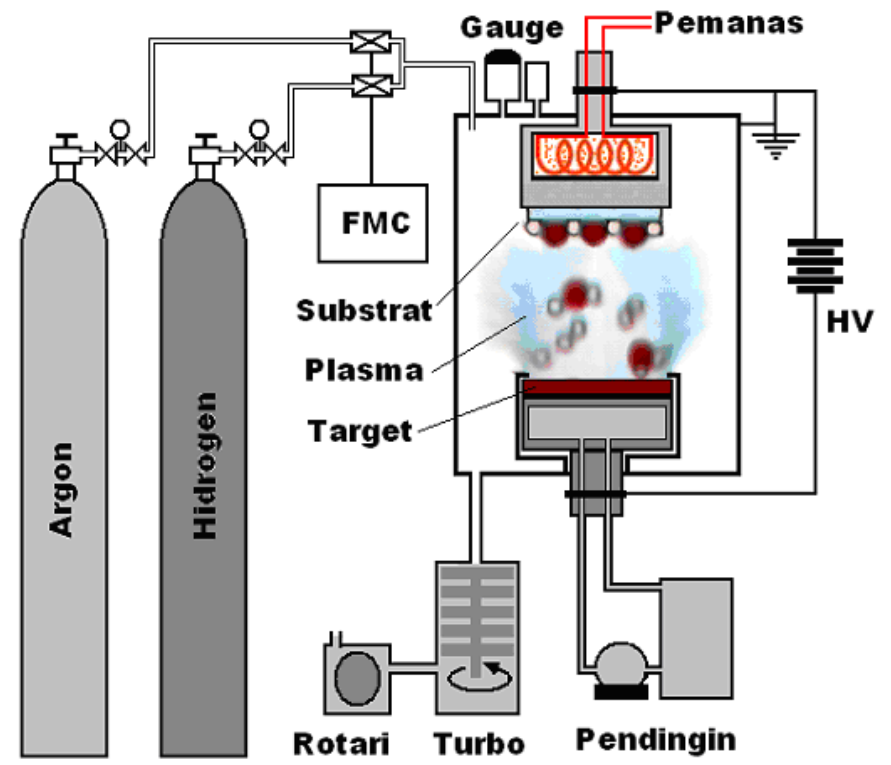

Gambar 1. Skema Peralatan Plasma Sputtering DC.

\section{Karakterisasi Sifat Listrik Lapisan Tipis (a-Si:H:B)}

Besar resistivitas pada lapisan tipis dapat diukur dengan mengunakan probe empat titik, yaitu suatu jajaran empat probe diletakkan di atas lapisan tipis yang diukur resistivitasnya. Kemudian sumber tegangan dipasang pada dua probe terluar untuk menghasilkan arus diantara probe dalam. Dengan demikian pada probe bagian dalam akan timbul tegangan. Hasil yang telah didapat dianalisa berdasarkan hukum ohm, dalam hal ini bila lapisan tipis yang diukur mempunyai ukuran yang tidak terbatas atau bila tebalnya cukup besar dibandingkan dengan jarak antar probe resistivitasnya dapat didekati dengan persamaan ${ }^{\left[{ }^{[9}\right.}$ :

$$
\rho=(\pi V) /(I \ln 2)
$$

Tetapi bila tebal lapisannya lebih kecil dari jarak antar probe, maka persamaan (4) menjadi seperti persamaan (5) :

$$
\rho=(\pi V t) /(I \ln 2)
$$

dimana $t=$ tebal lapisan tipis, dan konduktivitasnya dapat dihitung sebagai kebalikan dari resistivitas,

$$
\sigma=1 / \rho
$$




\section{HASIL DAN PEMBAHASAN}

Parameter proses sangat berpengaruh terhadap hasil pelapisan, parameter tersebut diantaranya adalah : waktu deposisi, suhu substrat dan tekanan gas. Waktu deposisi akan mempengaruhi ketebalan lapisan yang terdeposisi, jadi bila waktu deposisi dinaikkan maka jumlah partikel maupun rapat lapisan yang tersputter juga makin bertambah, dengan demikian akibatnya kemungkinan partikel-partikel tersputer akan terdeposit di atas permukaan substrat juga semakin banyak sehingga hasil pelapisan akan bertambah tebal. Suhu substrat akan menyebabkan merenggangnya jarak antar atom sasaran sehingga akan mempermudah penyisipan atom-atom tersputter semakin dalam, akibatnya dapat dihasilkan lapisan yang rapat dan juga tebal, sedangkan tekanan gas akan mempengaruhi rapat plasma yang terbentuk dalam tabung reaktor.

Semikonduktor adalah suatu material yang mempunyai distribusi muatan yang beragam ${ }^{\left[{ }^{4}\right]}$ dan $j$ jika suatu lapisan tipis yang dihasilkan dari proses deposisi adalah kelebihan elektron dari pada holes, maka lapisan tipis tersebut mempunyai tipe- $N$ begitu pula sebaliknya akan mempunyai tipe- $P$. Dengan doping boron dapat menyebabkan Fermi level turun dibawah intrinsic level, dan semikonduktor (a-Si:H:B) mempunyai tipe-p. Biasanya semi-konduktor mempunyai konduktivitas diantara bahan isolator dan konduktor, jadi doping boron maupun hidrogen menjadikan konduktivitas lapisan tipis (a-Si:H:B) dapat ditentukan atau dikontrol.

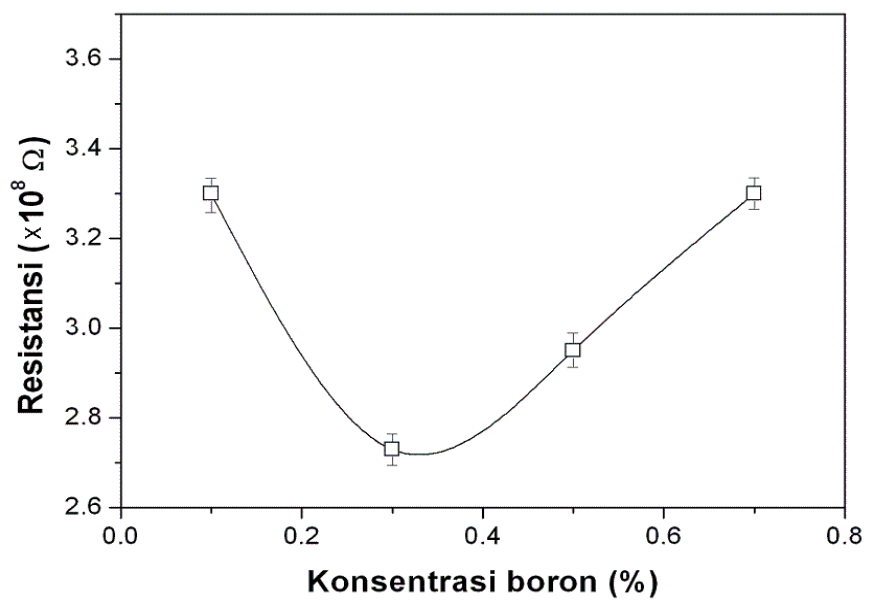

Gambar 2. Grafik resistansi vs konsen trasi boron, pada tekanan gas $1,4 \times 10^{-1}$ Torr, suhu substrat $200{ }^{\circ} \mathrm{C}$ dan waktu deposisi 1,5 jam.

Pada Gambar 2 tersebut terlihat berbagai nilai hasil pengukuran resistansi dari lapisan tipis (a-Si:H:B) yang telah berhasil dideposisikan di atas substrat kaca. Untuk target dengan konsentrasi boron $0,1 \%$, diperoleh nilai resistansi lapisan tipis (a-Si:H:B) yang dihasilkan sebesar $R=3,3 \square 108 \square$, sedangkan jika konsentrasi boron pada target dinaikkan menjadi $0,3 \%$, dapat diperoleh nilai resistansi yang lebih rendah yaitu $\mathrm{R}=2,730108 \mathrm{\square}$. Dengan asumsi bahwa lapisan tipis (a-Si:H:B) yang dihasilkan konsentrasi boronnya meningkat, hal ini menunjukkan adanya pengaruh konsentrasi boron terhadap resistansi lapisan tipis (a-Si:H:B). Dengan konsentrasi boron yang sangat rendah, kemungkinan lapisan tipis (a-Si:H:B) adalah masih tipe- $N$ dengan mayoritas elektron terkumpul didekat permukaan dan konsentrasi boron hanya berpotensi pada pembentukan lapisan tipis (a-Si:H). Selanjutnya jika konsentrasi boron ditingkatkan menjadi 0,3\% maka resistansi dari lapisan tipis (a-Si:H:B) menurun dan dalam keadaan ini mungkin lapisan tipis (a-Si:H:B) mempunyai tipe- $P$ yaitu dengan kelebihan holes dan dalam keadaan yang optimum, maka kemungkinan akan diperoleh nilai resitansi yang minimum. Pada konsentrasi boron $0,5 \%$ dan $0,7 \%$ dihasilkan lapisan tipis (a-Si:H:B) dengan resistansi yang meningkat masing-masing menjadi $R=2,950108 \square$ dan $R=3,25 \square 108 \square$, hal ini dimungkinkan terjadinya penumpukan atom-atom boron terkonsentrasi pada permukaan lapisan tipis sehingga mengakibatkan resistansi yang meningkat pula dan bahkan terjadi pembentukan lengan-lengan kosong (dangling bond) yang berlebihan. ${ }^{[]}$ 
Gambar 3 adalah grafik resistansi dengan variasi suhu substrat pada tekanan gas $1,4 \times 10^{-1}$ Torr, waktu deposisi 1,5 jam dan konsentrasi Boron 0,3\%. Dari Gambar 3 tersebut menunjukkan bahwa pada suhu substrat $150{ }^{\circ} \mathrm{C}$ resistansi lapisan tipis (a-Si:H:B) sebesar $\mathrm{R}=3,26 \times 10^{8} \Omega$, namun setelah suhu substrat dinaikkan lagi menjadi $200{ }^{\circ} \mathrm{C}$ maka nilai resistansinya terus menurun dan diperoleh nilai yang minimum sebesar $R=2,73 \times 10^{8} \Omega$.

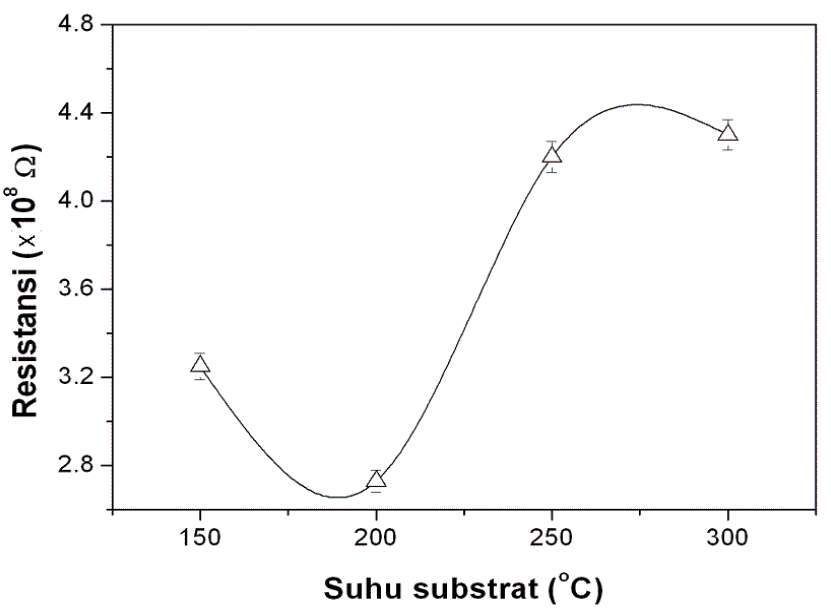

Gambar 3. Grafik resistansi vs suhu substrat, pada tekanan gas $1,4 \times 10^{-1}$ Torr, konsentrasi boron $0,3 \%$, waktu deposisi 1,5 jam.

Hal ini kemungkinan disebabkan suhu pemanasan substrat, sehingga terjadi perenggangan jarak antar bidang atom sehingga akan mempermudah terjadinya penyisipan (interstition) partikel tersputter. Dengan demikian atom-atom target sepenuhnya mengisi rongga-rongga yang terbentuk akibat pemanasan substrat, sehingga hasil lapisan deposisi menjadi sangat rapat dan akibatnya dapat diperoleh nilai resistansi yang rendah. Apabila suhu substrat dinaikkan terus, maka yang terjadi adalah bahwa atom-atom target yang tersputter terus menyisip dan ketebalan lapisan juga meningkat. Namun demikian setelah suhu substrat dinaikkan mejadi 250 ${ }^{\circ} \mathrm{C}$ dan $300{ }^{\circ} \mathrm{C}$, diperoleh hasil pengukuran resistansi yang meningkat menjadi masing- masing sebesar $\mathrm{R}=$ $4,2 \times 10^{8} \Omega$ dan $R=4,3 \times 10^{8} \Omega$, dalam hal ini suhu substrat melebihi nilai optimumnya. Sebagai akibatnya nilai resistansinya terus meningkat, dan mungkin terjadi juga penumpukan atom-atom target tersputter pada permukaan substrat sewaktu proses deposisi sehingga hasil lapisannya tidak rapat/porous. Dan karena kualitas dari lapisan tipis (a-Si:H:B) tersebut, maka akan menyebabkan meningkatnya resistansi atau menimbulkan hambatan terhadap arus listrik yang mengalir pada saat pengukuran.

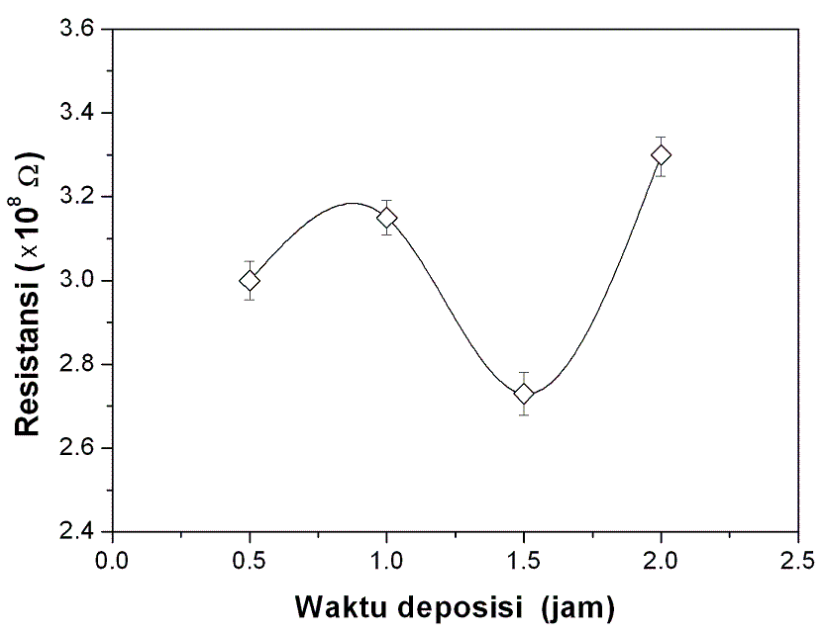

Gambar 4. Grafik resistansi vs waktu deposisi, pada tekanan gas $1,4 \times 10^{-1}$ Torr, suhu substrat $200{ }^{\circ} \mathrm{C}$ dan konsentrasi boron $0,3 \%$. 
Gambar 4 adalah grafik resistansi sebagai fungsi variasi waktu deposisi, pada tekanan gas $1.4 \times 10^{-1}$ Torr, suhu substrat $200{ }^{\circ} \mathrm{C}$ dan konsentrasi boron $0,3 \%$. Dari gambar tersebut terlihat bahwa nilai resistansi terkecil untuk lapisan tipis (a-Si:H:B) dicapai pada waktu deposisi 1,5 jam yaitu sebesar $R=2,73 \times 10^{8} \Omega$, ini mungkin merupakan parameter proses deposisi yang optimum untuk variasi waktu deposisi. Hal ini terjadi karena bertambahnya waktu deposisi menyebabkan jumlah partikel yang tersputter per satuan luas juga meningkat dan kebolehjadian atom-atom target terdeposit pada permukaan substrat semakin besar. Lapisan tipis (a-Si:H:B) yang terbentuk juga bertambah rapat dan tebal, sehingga menyebabkan nilai resistansinya menurun. Sedangkan untuk waktu deposisi 0,5 dan 1 jam diperoleh nilai resistansi (a-Si:H:B) sebesar $R=3,0 \times$ $10^{8} \Omega$ dan $R=3,1 \times 10^{8} \Omega$, ini menunjukkan nilai resistansi yang lebih besar, dan kemungkinan partikel hasil sputtering belum mencukupi untuk terdeposit pada luasan substrat dan menghasilkan lapisan yang sangat tipis dan renggang, sehingga nilai resistansinya juga tinggi. Namun demikian jika waktu deposisi ditingkatkan menjadi 2 jam diperoleh nilai resistansi yang meningkat pula yaitu sebesar $R=3,3 \times 10^{8} \Omega$, hal ini mungkin disebabkan terjadinya penumpukan atom-atom tersputter pada permukaan substrat, sehingga kualitas dari lapisan (a-Si:H:B) tidak rapat/porous.

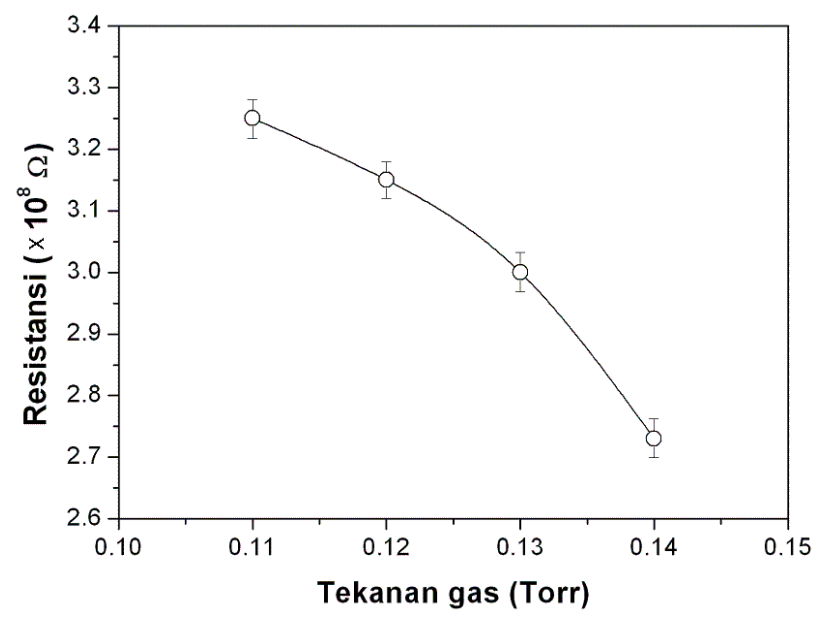

Gambar 5. Grafik resistansi vs tekanan gas, untuk waktu deposisi 1,5 jam, suhu substrat $200{ }^{\circ} \mathrm{C}$, dan konsentrasi boron $0,3 \%$.

Gambar 5 adalah grafik resistansi dengan variasi tekanan gas pada waktu deposisi 1,5 jam, suhu substrat $200{ }^{\circ} \mathrm{C}$ dan konsentrasi boron $0,3 \%$. Dari gambar tersebut terlihat bahwa pada tekanan gas $1,1 \square 10^{-1}$ Torr diperoleh nilai resistansi dari hasil deposisi (a-Si:H:B) sebesar $\mathrm{R}=3,25 \square 10^{8} \square$, jika tekanan gas dinaikkan maka diperoleh nilai resistansi yang terus menurun hingga mencapai resistansi yang minimum sebesar $R=2,73$ $\square 10^{8} \square$ pada tekanan $1,4 \square 10^{-1}$ Torr (tekanan optimum). Pada tekanan $1,1 \square 10^{-1}$ hingga $1,3 \square 10^{-1}$ Torr, hasil pengukuran resistansi masih lebih tinggi dibandingkan pada kondisi optimumnya, hal ini disebabkan bahwa pada kondisi tersebut rapat plasma yang terbentuk belum optimum dan atom-atom hasil sputternya belum mencukupi untuk terdeposit pada substrat, sehingga diperoleh nilai resistansi yang lebih besar dari $R=2,73 \square 10^{8} \square$. Hal itu juga terjadi karena parameter tekanan gas dapat mempengaruhi rapat plasma yang terbentuk pada proses deposisi, dan bila energi plasma yang terbentuk masih rendah, kualitas lapisan tipis (a-Si:H:B) juga masih rendah dan resistansinya mungkin juga tinggi. Jika tekanan gas dinaikkan akan dihasilkan rapat plasma yang meningkat dan akibatnya energi sputternya juga meningkat sehingga atom-atom target hasil bombardir juga mempunyai energi yang cukup tinggi dan pada saatnya akan dicapai kondisi yang optimum dan dihasilkan kualitas lapisan tipis yang optimum juga. Tetapi jika energi plasma terlalu tinggi akibatnya juga akan terjadi energi balik (resputtering), ini tidak diinginkan dalam proses deposisi karena akan menyebabkan terjadinya kerusakan pada permukaan substrat, hal tersebut berlaku sesuai dengan persamaan (1) dan (2). 


\section{KESIMPULAN}

Dari beberapa hasil pengukuran lapisan tipis (a-Si:H:B) untuk berbagai parameter proses maka dapat disimpulkan bahwa:

1. Parameter proses deposisi waktu deposisi, tekanan gas dan suhu substrat sangat mempengaruhi kualitas hasil deposisi antara lain ketebalan, homogenitas dan kekuatan lapisan yang terbentuk pada substrat.

2. Diperoleh nilai resistansi lapisan tipis (a-Si:H:B) yang optimum sebesar $R=2,73 \times 10^{8} \Omega$. dicapai pada kondisi proses waktu deposisi 1,5 jam, tekanan gas $1,4 \times 10^{-1}$ Torr, suhu substrat $200{ }^{\circ} \mathrm{C}$ dan konsentrasi berat (B/Si) 0,3\%.

\section{UCAPAN TERIMA KASIH}

Terima kasih kepada Bpk. Drs. Darsono, M.Sc, APU., Bpk. Drs. BA. Tjipto Sujitno, MT, APU, yang telah banyak memberikan koreksi dan diskusinya, Bpk. Yunanto BE., atas diskusinya serta Bpk. Slamet Riyadi dan Bpk. Sumaji yang telah banyak membantu dalam eksperimen.

\section{DAFTAR PUSTAKA}

1. TAKAHASHI, K. and KONAGAI, M., Amorphous Silicon Solar Cells, North Oxford Academic Publishers Ltd., (1986).

2. MAKOTO KONAGAI, et. al , Photo-CVD Processing for Amorphous Silicon Solar Cell, PVSEC-6, New Delhi, India, 1992.

3. A. DASGUPTA, at al., P-layer of Mycro-crystalline Silicon Thin Film Solar Cells, $16^{\text {th }}$ European Photovoltaic Solar Energy Conference and Exhibition, 2000, in print.

4. KAI ZHU, et. Al., "Interfacial Optical in Amorphous Silicon Based Pin Solar Cells", Proceeding of the $28^{\text {th }}$ IEEE Photovoltaic Specialists Conference, Anchorage, September 19-22, 2000.

5. SWATI RAY, P.CHAUDURI, A.K. BATABYAL and A.K. BARUA, Electronic and Electrical Properties of Boron Doped Hydrogenated Amorphous Silicon Thin Films, Solar Energy Material 10(1984) 335-347.

6. ABHIJIT DE, SUKRITI GHOSH AND SWATI RAY, Boron Doped Hydrogenated Amorphous Silicon Films Prepared by Photo-CVD, Solar Energy Materials and Solar Cell 25 (1992) 137-147.

7. WASA, K., HAYAKAWA, S., Handbook of Sputter Deposition Technology: Principles, Technology and Application, Noyes Publication, New Jersey, 1992.

8. KONUMA M., Film Deposition by Plasma Techniques, Springer Verlag, Berlin, 1992.

9. HALLIDAY, RESNICK, PANTUN SILABAN, ERWIN SUCIPTO, Fisika, Erlangga, Jakarta, (1984). 